\title{
The Prediction of Wonogiri Dam's Service Life Using Point Integrated Sampling
}

\author{
Abas Pamuji $^{1 *}$, Sobriyah ${ }^{2}$, Cahyono Ikhsan ${ }^{2}$ \\ ${ }^{I}$ A Student of Civil Engineering Master Program, Engineering Faculty, Sebelas Maret University ${ }^{1}$ \\ ${ }^{2}$ Lecturers of Civil Engineering Master Program, Engineering Faculty, Sebelas Maret University ${ }^{2}$ \\ *Corresponding author: abas_pamuji@yahoo.com
}

\begin{abstract}
Sedimentation is the final process of erosion event due to run off, in which the soil grain is brought with through cavity, water channel toward the river then ends up in the reservoir. As a result, the reservoir will be filled in with sediment, so that the uncontrolled sediment will affect the reservoir's service life. Point integrated sampling method is an alternative to find out the reservoir's service life. The case study is conducted in multi-purpose Wonogiri reservoir, using the following instruments: GPS, dradloading set, meters, with maps from RBI and surfer software help to develop the sounding channel grids and to get the reservoir's contour map. Point integrated sampling is a method of measuring the reservoir's depth directly using dradloading with the large number of taking point with integrated sounding channel grids to obtain the elevation of sediment deposition currently. Then the data of reservoir's elevation result was processed using surfer software. During running, it could be seen that the reservoir's elevation increased compared with the original one during preparation because there is sediment deposition in the bottom of reservoir, so the reservoir's sedimentation could make the reservoir's dead storage full there by reducing the reservoir's service life.
\end{abstract}

Keywords—Sediment, Surfer, Point Integrated Sampling

\section{INTRODUCTION}

The consequence of river water accommodation in the reservoir (dam) is that the sediment carried with by water flow will be accommodated as well, in the form of either suspended load or bad load. So much sedimentation depositing in the dam is one factor constraining the dam's accommodating capacity, so that the volume of sedimentation in the dam is usually used to estimate the dam's service life. Therefore, for the estimation of dam's service life to be accurate and the preservation and security of dam to be implemented as planned, data, knowledge and in-depth analysis on dam sedimentation are required. The large volume of sedimentation can reduce the capacity and function of dam, and can lead to the expensive operational and maintenance cost for the dam. Sediment occurring in the dam can also result in sedimentation thereby reducing the dam's accommodating capacity. The reduced accommodating capacity will impact on the function of dam itself, particularly in providing irrigation water, standard water and PLTA (Water Electricity Generator).

The data of Balai Besar Wilayah Sungai Bengawan Solo suggests that the water volume of Wonogiri Dam shrinks from original volume of \pm 440 millions $\mathrm{m}^{3}$ into \pm 375 millions $\mathrm{m}^{3}$ (in 2005); it is presumably because Wonogiri dam has encountered sufficiently high sedimentation process. Such condition is worrying because it can harm the function of dam thereby reduce the service life of Wonogiri Dam.

The consequences of river water reservoirs in the reservoir will also be accommodated as well as sediments carried by the water flow, both in the form of suspended loads and bad deposits. The amount of sedimentation that settles in the reservoir is one limiting factor to the reservoir storage capacity, so that the amount of sediment deposition in the reservoir is commonly used to determine the service life of the reservoir. Therefore, the estimated usefulness of the reservoirs to be accurate and the preservation and safety of the reservoirs can be accomplished as planned, a substantial amount of data, knowledge and analysis on reservoir sedimentation is required. Large amounts of sedimentation can reduce the capacity and function of the reservoir, and may result in the high cost of operation and maintenance of the reservoir.

\section{METHOD}

Some researchers, for example [1], explains that sedimentation is the accumulation of sediment on a location due to both surface erosion and slope erosion occurring in the catchment and carried with by the water flow into the dam [2]. Sedimentation can reduce the function of dam so that it can be utilized optimally. The volume of sediment is the important factor used in estimating the service life of dam [3]. Sediment can reduce the service life of dam directly, thereby affecting the advantage of dam [4].

\section{Sedimentation in the dam}

To deal with various problems existing in the dam, we are often required to find out the characteristics of sediment material, as either bulk or grain (individual). Hydraulicists argue that the sediment grain can affect the depositing speed, basic sediment transporting process, and etc. By its grain, sediment transportation can occur in two ways:

- Bed load.

I It is the movement of grain in the bottom of channel in rolling, sliding and jumping ways. 
August $1^{\text {st }}$ Suspended Purgbaya - Indonesia

It is the movement of grain in the bottom of channel, in which it is compensated continuously by water turbulence or by diffusion action of turbulent flow field.

Dam is a waterworks serving to retain river water. The consequence of river water retaining is that the sediment will be carried with by the river water flow. Much sediment entering into the dam is affected by some factors: physiographic and hydroclimatological factors of catchment area.

Meanwhile the volume of sediment depositing in the dam is affected by sediment type, dam shape and dimension, sediment volume and dam's operational pattern. Some human activities also contribute to improving the surface erosion rate: land use in the dam catchment, settlement construction and other infrastructure construction. Another factor affecting the strategy of managing dam sediment is precision in predicting the sediment yield, as it will be used in sedimentation management system and dam's operational pattern. Overestimate condition makes the operational system expensive, while underestimate condition will result in the reduced service life of dam.

\section{Service Life of Dam}

The service life of dam is planned based on how long the dam's accommodating capacity can be maintained and unfilled in by sediment deposition.

Theoretically, the dam's service life can be estimated by the dam's sedimentation rate likely occurring and
$S_{r}=\frac{V_{s}}{t_{2}-t_{1}}$

Where:

$\mathrm{Sr} \quad=$ Dam's sedimentation rate $(\mathrm{m} 3 / \mathrm{yr})$.

$\mathrm{Vs}=$ Depositing Sediment Volume (m3).

$\mathrm{t}_{2}=$ Present time (year).

$\mathrm{t}_{1}=$ beginning time of operation (year).

The volume of sediment (Vs) is estimated based on the dam's elevation during the measurement subtracted with the dam's elevation during its construction and then multiplied with the dam width. In such the condition, the dam's service life can be calculated based on the dam's annual sedimentation rate and its dead storage. The service life of dam in year can be estimated using the formula below:

$$
L_{t}=\frac{V_{a}}{S_{r}}
$$

Where:

$\mathrm{Lt} \quad=$ Service Life of Dam (year).

$\mathrm{Va}=$ Accommodation volume (m3).

$\mathrm{Sr}=$ Sedimentation rate $(\mathrm{m} 3 /$ year $)$.

This research was taken place in Wonogiri Dam. It is a dam located in the south of Wonogiri Regency, Central Java Province. Wonogiri Dam is the dam in Bengawan Solo Main River serving as the flood controller, irrigation provider, and water electricity power generator Sedimentation in The Dam

In this research, the first step taken was to find secondary data, the data of dam construction's original

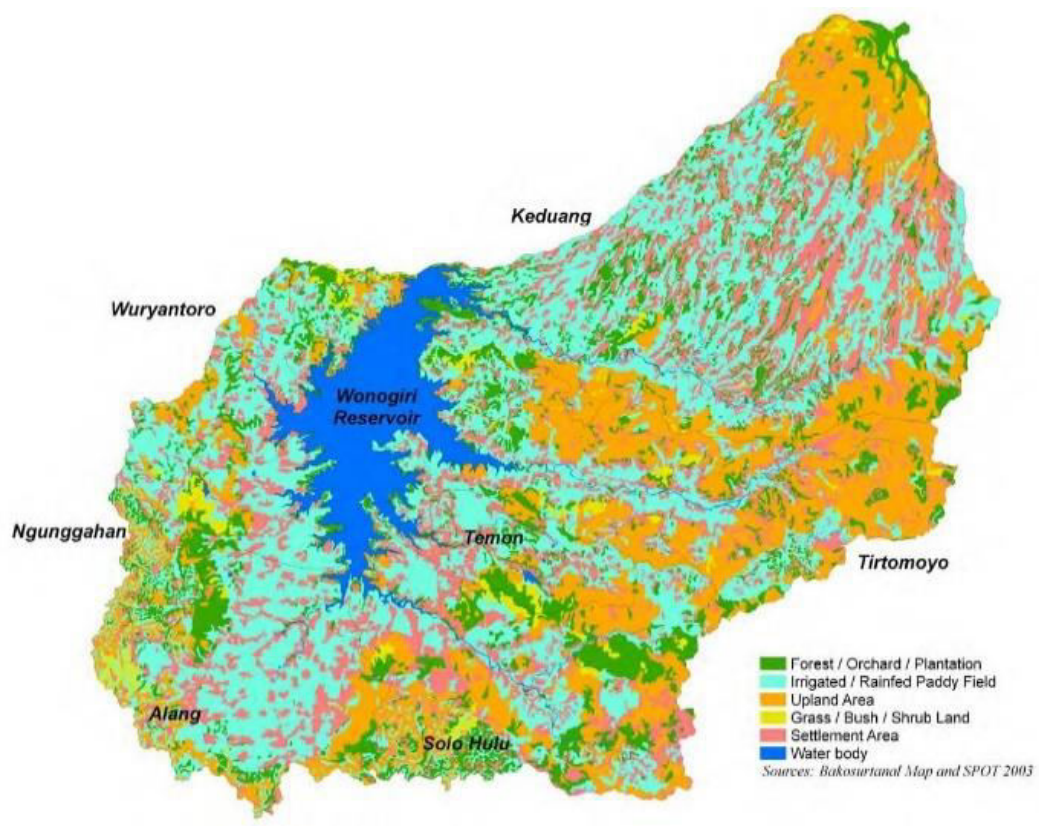

Figure 1. Map of wonogiri dam location

sediment accommodating volume or called dead storage provided.

The size of sedimentation rate ( $\mathrm{Sr}$ ) is estimated based on the volume of sedimentation resulting from the measurement divided with the period of time (year) to obtain the measure in cubic meter per year and can be calculated in the following formula: elevation, that will be used later to compare the original elevation condition and the current sediment elevation condition in order to obtain the sediment thickness currently. The next was to find primary data maps from RBI to develop the sounding line grids. The main instruments needed in this research were as follows: dam depth measuring instrument with dradloading technique, 
consisting of boat, GPS, wire, weight pendulum, iron plate ram, meters, gauge tub, stationery, and calculator.

Surfer is a grid-based mapping program that can interact the spots of irregular data XYZ into a regular spacing grid. Grids can also be used to generate various types of maps including base maps, contours, vectors, images, shaded reliefs, stream areas, 3D surfaces, and 3D Data wireframe maps. Surfer software can also be used to create profiles, and calculate the length, volume and extent of a map. Map results can be displayed and improved on the surfer, making it possible to produce the most representative map of data. We can add multiple map layers, customize the look of the map, so that it can create a map with publicity quality

Calculations using surfer software in principle begin with the depth of deskridi leveling at some point known coordinates. Flattening is done by creating a grid, so this method is also called gridding method. The smoothing technique depends on the number of grid points to be described and the number of closest points considered. The gridding method is intended to make the analysis of the point of depth obtained (either regularly or randomly)

This method was carried out using the following coordinate point using GPS; fourthly, we entered the dradloading into the dam down to the bottom of dam and we measured the depth of dam's basic elevation;

After the dradloading touched the bottom, we estimated the dradloading length entering into the water by considering the sign on the dradloading wire and we subtracted it with the dam's elevation during the measurement so that the current elevation of sediment can be obtained. Then, the data obtained from the survey was processed with surfer software help. Thus, the contour of dam could be found.

\section{Service Life of Dam}

Having obtained the result bathymetry from surfer aiming to get the map of dam's puddle and sediment thickness in the dam after having operated for many years, we compared the basic elevation of dam during the construction and the elevation of sediment during measurement thereby we would obtain the sediment thickness currently.

We only need to multiply it with the dam's current width to obtain the volume of sediment entering into the

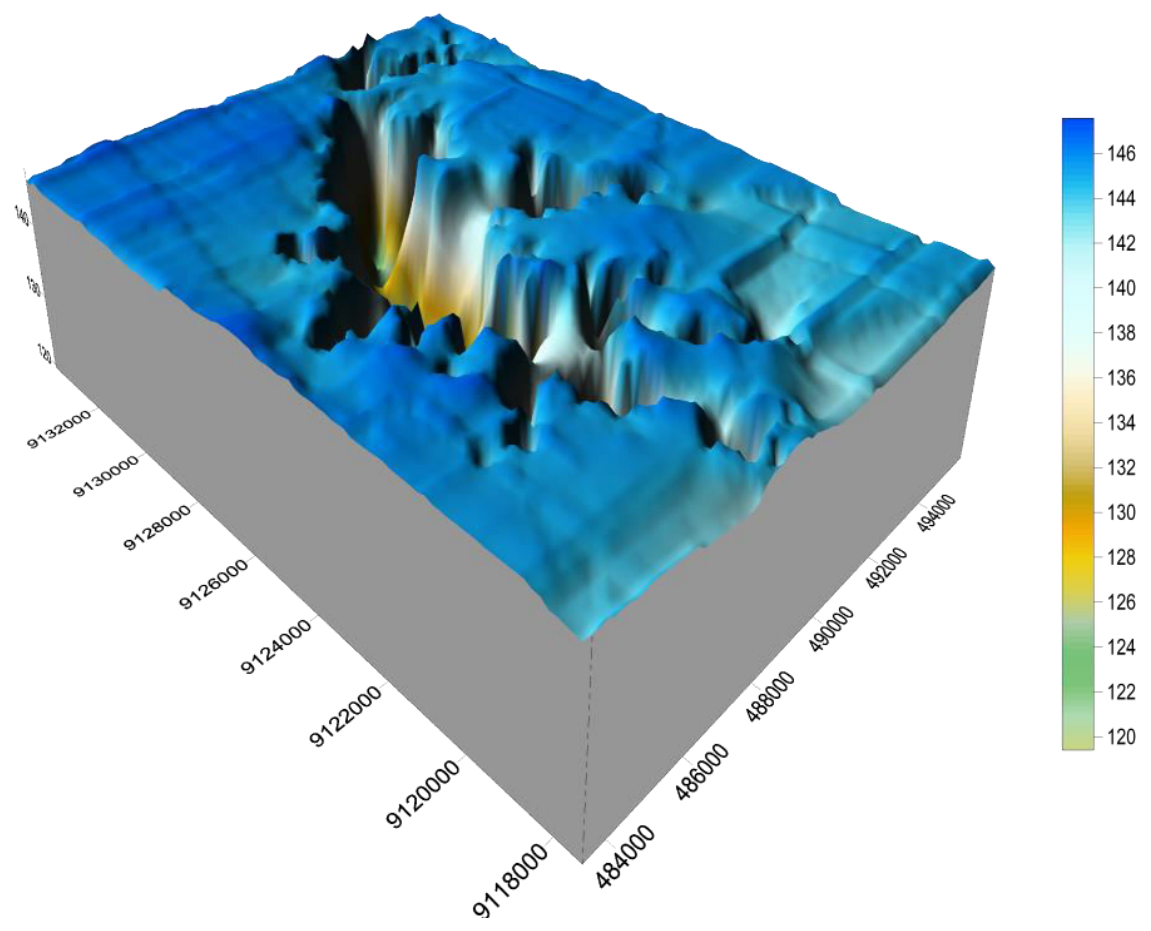

Figure 3. Elevasi at the time of the wonogiri dam measurement

order: Firstly, we prepared the survey and other supporting. Next, the measurement was conducted using point integrated sampling method. This measurement method was carried out by measuring the dam's depth directly using dradloading technique with the point integrated sampling to obtain water depth in one point, so that the basic elevation of dam on one point can be estimated from the water surface elevation during measurement subtracted with the water depth resulting from measurement. Then the data of dam's elevation result was processed using surfer software.

instrument; secondly we recorded the elevation of water surface at that time; thirdly, we recorded our dam. Thereafter, we would find the sedimentation rate occurring annually by dividing the volume of sediment having entered into the dam by the year elapsing. Thus, the service life of dam could be found by dividing the dam's accommodation by the sedimentation rate per year.

Based on the calculation of computer grid volume with surfer software it is found that the volume of water in the reservoir at the current elevation is 343.767 .861 $\mathrm{m}^{3}$. 


\section{RESULT AND DISCUSSION}

The volume of water in the dam during planning is 441.755.514 m. Sedimentation in Wonogiri dam during 1981-2017 based on the dradloading measurement with point integrated sampling conducted in Wonogiri dam shows that there is a sufficiently serious sedimentation. From the information obtained in the Grid Volume Computations report

Sedimentation rate in Wonogiri dam can be estimated based on sediment volume from the result of measurement divided by the years elapsing.

$$
\begin{aligned}
& S_{r}=\frac{V_{s}}{t_{2}-t_{1}} \\
& =\frac{441,755514-343,767861 \text { million } \mathrm{m}^{3}}{2017-1981} \\
& =\frac{97,987653 \text { million } \mathrm{m}^{3}}{36 \text { year }} \\
& =2,721879 \text { million } \mathrm{m}^{3} / \text { years }
\end{aligned}
$$

The service life of dam is estimated using the dam's dead storage. When the dead storage has been filled in with sediment, the normal service will be harmed thereby the service life of dams is considered as having used up. The service life of dam can be estimated by dividing dead storage volume with the dam's sedimentation rate per year.

$$
\begin{aligned}
L_{t} & =\frac{V_{a}}{S_{r}} \\
& =\frac{120 \text { million } \mathrm{m}^{3}}{2,721879 \text { million } \mathrm{m}^{3} / \text { years }}=44 \text { years }
\end{aligned}
$$

\section{CONCLUSION}

From the result of discussion, the following conclusions could be drawn:

1. From the result of survey in the field using dradloading technique with a surfer-based point integrated sampling, it could be found that the volume of sediment depositing in the dam is 97,987653 millions $\mathrm{m} 3$, and sedimentatin rate is 2,721879 millions/year.

2. The service life of dam is estimated by dividing its dead storage volume with the sedimentation rate per year. Thus, it can be found that the service life of dam is 44 year from the dam's planned life of 100 years.

\section{AKNOWLEDGEMENT}

On this occasion the author would like to say thank you as much as possible to:
1. Dr. Eng. Ir. Syafi'i, M.T., as Head of Master Program of Civil Engineering Sebelas Maret University Surakarta.

2. Dr. Cahyono Ikhsan, S.T., M.T., as Supervisor I.

3. Prof. Dr. Ir. Sobriyah, M.S., as Supervisor II.

4. Dr. Ir. Rr, Rintis Hadiani M.T., as a Lecturer Examiner.

5. The entire staff of the Master Program in Civil Engineering Sebelas Maret University Surakarta who has helped many authors during lectures.

6. My beloved family that continues to give prayers, passion and support both morally and materially in completing this education.

7. Fellow students of Master Program in Civil Building Rehabilitation and Maintenance Engineering.

8. All parties who have assisted the author in completing this thesis, which can not authors mention one by one

\section{REFERENCES}

[1] S. . Wahyudi, "Sutami Malang. Jurnal Rekayasa Sipil Universitas Brawijaya, Vol. 1, No. 1. [11] Wahyudi, S.I., 2004. Pengaruh Sedimentasi Terhadap Kapasitas dan Operasional Waduk (Studi Kasus: Waduk Cacaban)," J. Unimus, 2004.

[2] M. Nursa'ban, "Evaluasi Sediment Yield Di Daerah Aliran Sungai Cisanggarung Bagian Hulu Dalam Memperkirakan Sisa Umur Waduk Darma (Studi Kasus : Waduk Darma)," J. Penelit. saintek, vol. 13, no. 1, 2008.

[3] J. S. Fidari, "Studi pendugaan sisa usia guna waduk sutami dengan Pendekatan sedimentasi," J. Pengair. Univ. Brawijaya, vol. 4, no. 2, 2013.

[4] E. Setyono, "Kajian Distribusi Sedimentasi Waduk Wonorejo,Tulungagung-Jawa Timur (Studi Kasus: Waduk Wonorejo)," Media Tek. Sipil Univ. Muhamammadiyah Malang, vol. 9, no. 2, pp. 132-141, 2011.

[5] Achsan, Dkk. 2015. Analisis Kecenderungan Sedimentasi Waduk Bili-Bili Dalam Upaya Keberlanjutan Usia Guna Waduk (Studi Kasus : Waduk Bili-Bili). Jurnal Teknik Pengairan Universitas Brawijaya, Vol. 6, No. 1, Hlm. 30-36.

[6] Anonim. 2009. Survey dan Monitoring Sedimentasi Waduk. Departemen Pekerjaan Umum. Direktorat Jenderal Sumber Daya Air. Jakarta.

[7] Darmono. 2005. Prediksi Umur Waduk Panglima Jendral Sudirman Berdasakan Hasil Pengukuran Echo-Sounding (Studi Kasus : Waduk Panglima Jendral Sudirman). Jurnal Teknik Sipil dan Arsitektur Universitas Negeri Yogyakarta, Vol. 1, No. 2.

[8] Elci, S., et al. 2009. Using numerical models and acoustic methods to predict reservoir sedimentation (Study : Tahtali Reservoir). Lake and Reservoir Management, 25:3

[9] Ikhsan, C. 2009. Angkutan Sedimen Sungai. Diklat Kuliah Magister Teknik Rehabilitasi dan Pemeliharaan Bangunan Sipil (MTRPBS), Universitas Sebelas Maret, Surakarta.

[10] Jain, S.K., et al. 2009. Assessment of sedimentation in Bhakra Reservoir in the western Himalaya region using remotely sensed data (Study: Bhakra Reservoir). Hydrological Sciences, 47.

[11] Suroso, M., Dkk. 2007. Studi Pengaruh Sedimentasi Kali Brantas Terhadap Kapasitas Dan Usia Rencana Waduk Sutami Malang. Jurnal Rekayasa Sipil Universitas Brawijaya, Vol. 1, No. 1. 